\title{
Disseminated Herpesvirus hominis (Herpes simplex) infection: retrospective diagnosis by light and electron microscopy of paraffin wax-embedded tissues
}

\author{
A. G. ROSE AND W. B. BECKER ${ }^{1}$ \\ From the Departments of Pathology and of Bacteriology and MRC Virus Research Unit, University of Cape \\ Town Medical School
}

SYNOPSIS Disseminated Herpesvirus hominis infection had previously been reported from other parts of the world, but the disease was initially recognized at necropsy in Cape Town in 1957 (McKenzie, Hansen, and Becker, 1959).

The present retrospective study established that the disease had been occurring before 1957 but that its aetiology had not been recognized. An awareness of the disease, together with an adequate knowledge of the clinical history, the morbid anatomy, and histology of the lesions, usually allows a confident diagnosis to be made.

Hass (1935) described a case of disseminated Herpes simplex infection with necrotic lesions of the liver and adrenal in a premature infant. Since then there have been numerous reports of disseminated disease in neonates and also in older children.

The association of disseminated herpesvirus infection with malnutrition in children after the neonatal period was first recognized in Cape Town in 1957 (McKenzie et al, 1959; McKenzie, 1961). If this disseminated disease caused by the ubiquitous Herpesvirus hominis (Becker, 1966) occurred for the first time in 1957 it would suggest precipitating factors such as the emergence of a more virulent strain of the virus. An alternative explanation would be that similar cases were seen before 1957, but that their viral aetiology was not appreciated at the time. The postmortem findings and the histology in the florid cases are distinctive enough (McKenzie et al, 1959; Becker, Naude, Kipps, and McKenzie, 1963) so a retrospective examination of necropsy material before 1957 was undertaken in an attempt to resolve this issue.

\section{Materials and Methods}

\section{NECROPSIES}

The necropsy records from 1949 to 1957 inclusive

'Present address:Department of Virology, University of Stellenbosch Medical School, Private Bag 4, Tiervlei, Cape

Received for publication 9 June 1971. were consulted and the histology was reviewed in all cases in which any of the following pathological changes were recorded: liver necrosis (including miliary tubercles), adrenal haemorrhage or necrosis, digestive tract ulceration (non-peptic), splenic infarction, atypical forms of pneumonia, and severe malnutrition. The tissue sections of 207 of a total of 5,051 necropsies were re-examined and disseminated herpetic infection was diagnosed in six cases. Liver necrosis, which was considered to be non-herpetic in origin, was noted in 82 other cases, and five of these were used as controls for the six herpetic cases in carrying out electron microscopy on the liver lesions.

EXPERIMENTALLY INFECTED WHITE MICE

Suckling and 3-week-old white mice (local highly inbred strain) were inoculated intraperitoneally with 800-1000 TCID $_{50}$ of Herpes virus hominis strain E47 liver which had been passed four times in cultures of vervet monkey kidney cells (Cercopithecus aethiops pygerythrus). All the mice died and showed focal liver necroses. Portions of the livers of four of the mice and of one control uninoculated mouse were fixed in $10 \%$ formol-saline and embedded in paraffin wax by routine methods; other portions were fixed in alcohol and embedded in paraffin wax for immunofluorescent studies (Sainte-Marie, 1962). The herpetic aetiology of the focal necroses was confirmed by the characteristic histological features, 
by specific immunofluorescence, and by the demonstration of herpesvirus particles in the liver lesions by electron microscopy.

\section{ELECTRON MICROSCOPY}

Several methods have been described for the examination of wax-embedded tissues by electron microscopy (Zagury, Zeitoun, and Viette, 1966; Descarries, 1967; Morecki and Becker, 1968; Zagury, Pappas, and Marcus, 1968). The method used was as follows: paired sections were cut from the paraffin blocks, one $5-8 \mu$ thick for routine haematoxylin and eosin staining and the other $20-80 \mu$ thick. A lesion with suitable landmarks was selected on the stained section so that the corresponding area on the unstained thick section could be identified and removed with fine dissecting needles and processed for electron microscopy. As an alternative to the thick sections, the selected areas were in some cases removed directly from the block face if suitable landmarks were present.

The selected fragments were dewaxed in warm xylol, hydrated through graded ethanol solutions, fixed in osmic acid in veronal buffer $p \mathrm{H} 7.2$ for one hour at $4^{\circ} \mathrm{C}$, dehydrated through graded ethanol solutions and embedded in epon. Ultrathin sections were stained with lead citrate (Reynolds, 1963', followed by $5 \%$ uranyl acetate in distilled water, and examined in a Siemens Elmiskop $1 \mathrm{~A}$ at $80 \mathrm{Kv}$ and magnifications of 20,000 or 40,000 .
Results

CASE REPORTS

Six cases of disseminated herpesvirus infection were discovered (Table I). The first two cases, one a white neonate, the second a malnourished 8-month-old coloured child, were examples of children dying from florid disseminated herpetic infection with extensive liver necrosis as described in previous publications (McKenzie et al, 1959; Becker et al, 1963; Becker, Kipps, and McKenzie, 1968). In the remaining four cases the herpetic infection was not the dominant feature. In addition to the herpetic necroses in the liver, there were also portal pyaemic lesions in the liver in case 4 and miliary tubercles in case 6 . All but the neonate were malnourished.

\section{Case 1}

A 12-day-old white female died from an illness characterized by pyrexia, jaundice, diarrhoea, and attacks of apnoeic cyanosis. Hepatomegaly was noted two days before death. Septicaemia was diagnosed. The morbid anatomical and histological findings (Fig. 1) of florid disseminated Herpesvirus hominis infection were striking, but were not recognized as such. Death was due to the herpesvirus infection.

\section{Case 2}

An 8-month-old male coloured infant was admitted

\begin{tabular}{|c|c|c|c|c|c|c|c|c|c|}
\hline \multirow{2}{*}{$\begin{array}{l}\text { Case/Post- } \\
\text { mortem } \\
\text { No. }\end{array}$} & \multirow{2}{*}{$\begin{array}{l}\text { Race, Sex, } \\
\text { Age }\end{array}$} & \multirow{2}{*}{$\begin{array}{l}\text { Malnutri- } \\
\text { tion }\end{array}$} & \multirow{2}{*}{$\begin{array}{l}\text { Days in } \\
\text { Hospital }\end{array}$} & \multirow{2}{*}{$\begin{array}{l}\text { Herpetic } \\
\text { Ulceration of } \\
\text { Mucous } \\
\text { Membranes }\end{array}$} & \multicolumn{3}{|l|}{ Liver } & \multirow{2}{*}{$\begin{array}{l}\text { Herpesvirus } \\
\text { - Particles } \\
\text { in Liver by } \\
\text { Electron } \\
\text { Microscopy }\end{array}$} & \multirow{2}{*}{$\begin{array}{l}\text { Other Relevant } \\
\text { Data }\end{array}$} \\
\hline & & & & & Macroscopically & Microscopically & $\begin{array}{l}\text { Percentage } \\
\text { of Liver } \\
\text { Necrosis }\end{array}$ & & \\
\hline $\begin{array}{l}1 \\
289 / 1951\end{array}$ & $\begin{array}{l}\text { E.F. } 12 \\
\text { days }\end{array}$ & - & 12 & Oesophagus & \multirow{2}{*}{\multicolumn{2}{|c|}{$\begin{array}{l}\text { Classical florid disseminated } \\
\text { herpesvirus infection } \\
\text { Classical florid disseminated } \\
\text { herpesvirus infection } \\
\text { Fatty liver }\end{array}$}} & 85 & $\cdots$ & - \\
\hline $\begin{array}{l}2 \\
22 / 1954\end{array}$ & $\begin{array}{l}\text { C.M. } 8 \\
\text { months }\end{array}$ & $\because$ & 1 & $\begin{array}{l}\text { Mouth and } \\
\text { nose }\end{array}$ & & & 60 & $T$ & - \\
\hline $\begin{array}{l}3 \\
42 / 1954\end{array}$ & $\begin{array}{l}\text { B.M. } 5 \\
\text { months }\end{array}$ & - & 27 & Not recorded & Yellow foci & $\begin{array}{l}\text { Herpetic lesions, } \\
\text { sparse inclusions, } \\
\text { mild cellular } \\
\text { response }\end{array}$ & 50 & $\therefore$ & $\begin{array}{l}\text { Septic thrombo- } \\
\text { plebitis, lung } \\
\text { abscess and } \\
\text { empyema }\end{array}$ \\
\hline $\begin{array}{l}4 \\
43 / 1954\end{array}$ & $\begin{array}{l}\text { B.F. } 12 \\
\text { months }\end{array}$ & $\therefore$ & 25 & Not recorded & Yellow foci & $\begin{array}{l}\text { Portal pyaemia, } \\
\text { herpetic lesions } \\
\text { with mild cellular } \\
\text { response }\end{array}$ & 10 & $\div$ & $\begin{array}{l}\text { Pneumonia, } \\
\text { septicaemia, } \\
\text { Mantoux } \\
\text { negative }\end{array}$ \\
\hline $\begin{array}{l}5 \\
148 / 1954\end{array}$ & $\begin{array}{l}\text { C.M. } 18 \\
\text { months }\end{array}$ & ... & 22 & $\begin{array}{l}\text { Mouth, } \\
\text { tongue, } \\
\text { pharynx, } \\
\text { oesophagus }\end{array}$ & $\begin{array}{l}\text { Yellow-grey } \\
\text { foci }\end{array}$ & $\begin{array}{l}\text { Herpetic lesions, } \\
\text { sparse inclusions, } \\
\text { mild cellu!ar } \\
\text { response }\end{array}$ & 10 & $\div$ & $\begin{array}{l}\text { Pulmonary } \\
\text { tuberculosis, } \\
\text { Mantoux } \\
\text { negative }\end{array}$ \\
\hline $\begin{array}{l}6 \\
208 / 1957\end{array}$ & $\begin{array}{l}\text { C.F. } 6 \\
\text { months }\end{array}$ & $\ldots$ & 7 & $\begin{array}{l}\text { Mouth, } \\
\text { tongue, } \\
\text { oesophagus, } \\
\text { pharynx, } \\
\text { larynx }\end{array}$ & Many tubercles & $\begin{array}{l}\text { Tubercles but } \\
\text { also herpetic } \\
\text { lesions with } \\
\text { sparse inclusions, } \\
\text { good cellular } \\
\text { response }\end{array}$ & 10 & - & $\begin{array}{l}\text { Pulmonary and } \\
\text { miliary tuber- } \\
\text { culosis, Mantoux } \\
\text { negative }\end{array}$ \\
\hline
\end{tabular}

Table I Data on six children with disseminated Herpesvirus hominis infection 


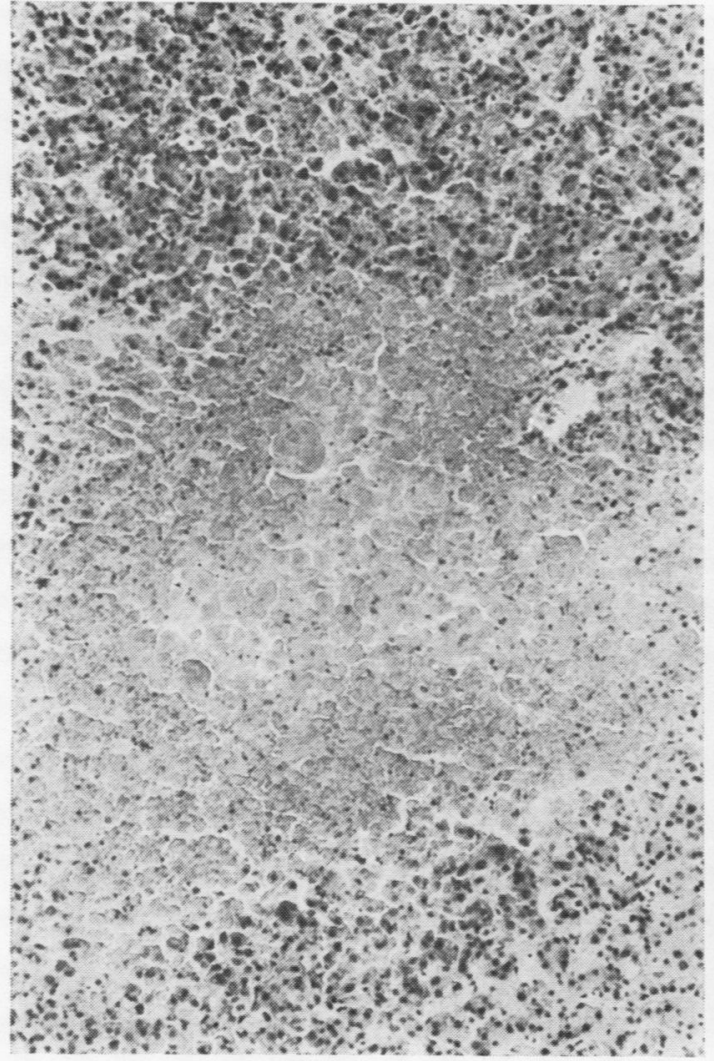

A

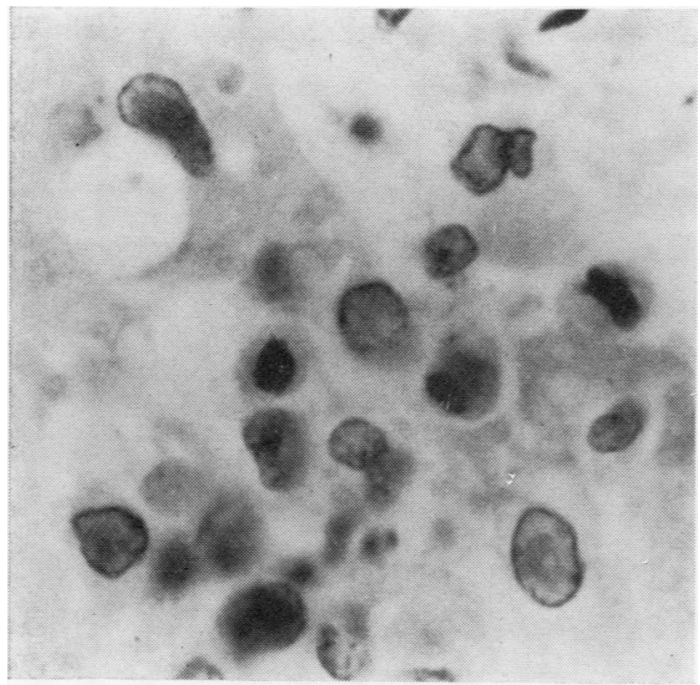

A $A$ focus of herpetic necrosis (haematoxylin and eosin, $\times 75$ ).

B Edge of the area of necrosis. Numerous herpetic intranuclear inclusion bodies were seen (haematoxylin and eosin, $\times 320$ ).

\section{Liver cells showing intranuclear inclusion bodies} (haematoxylin and eosin, $\times 1,200$ ).

Fig. 1 Case 1: histology of the liver from the neonate.

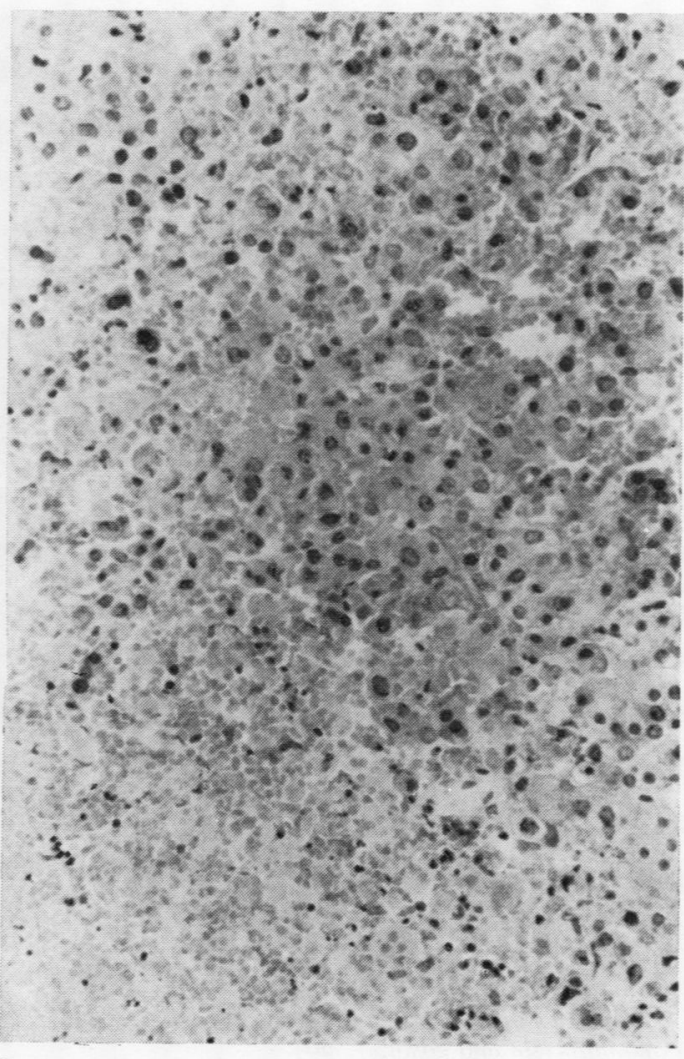

B 


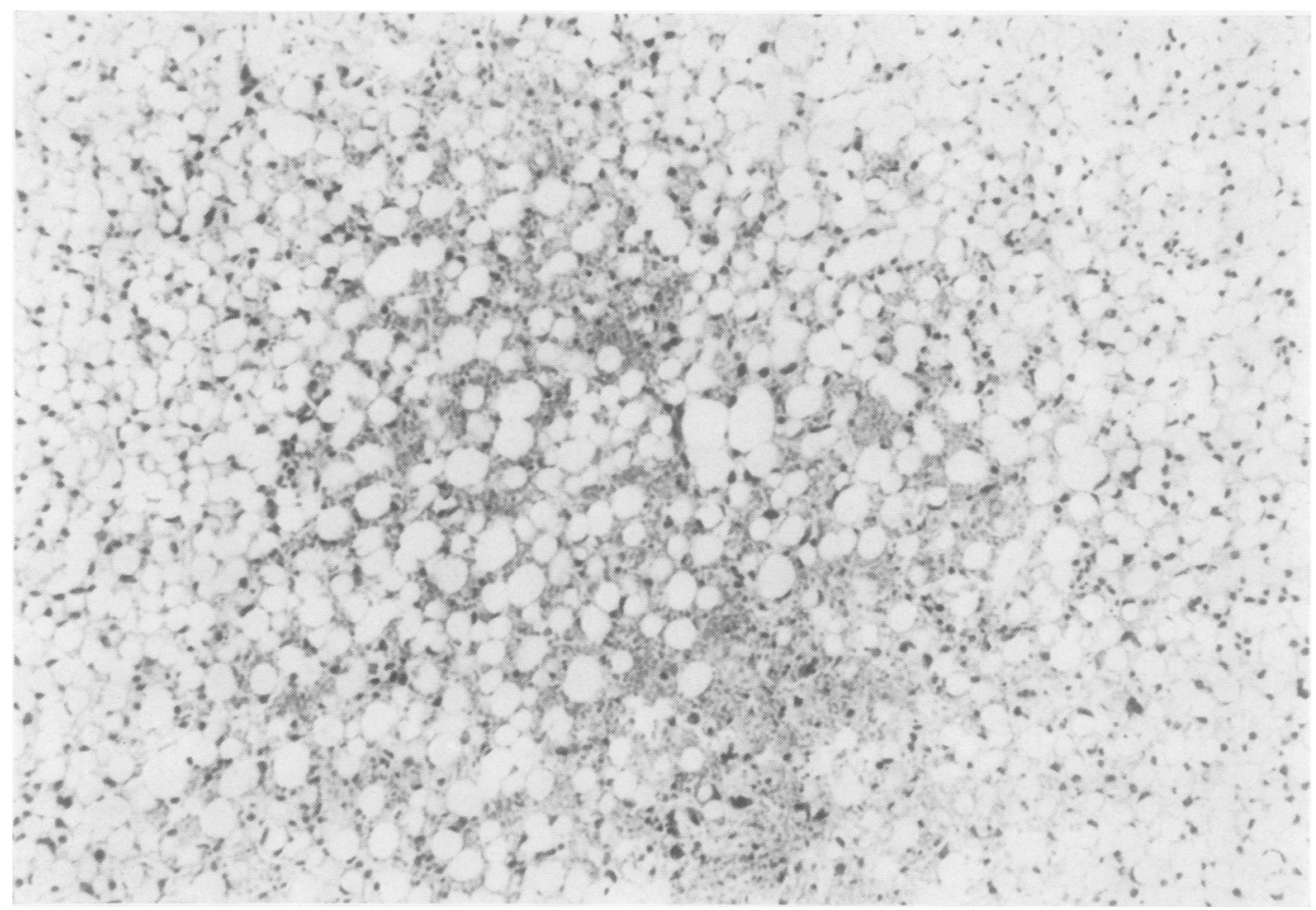

\section{A The focus of herpetic necrosis in the very fatty liver is conspicuous by the dilated, blood-filled sinusoids} (haematoxylin and eosin, $\times 50$ ).

Fig. 2 Case 2: histology of the liver.

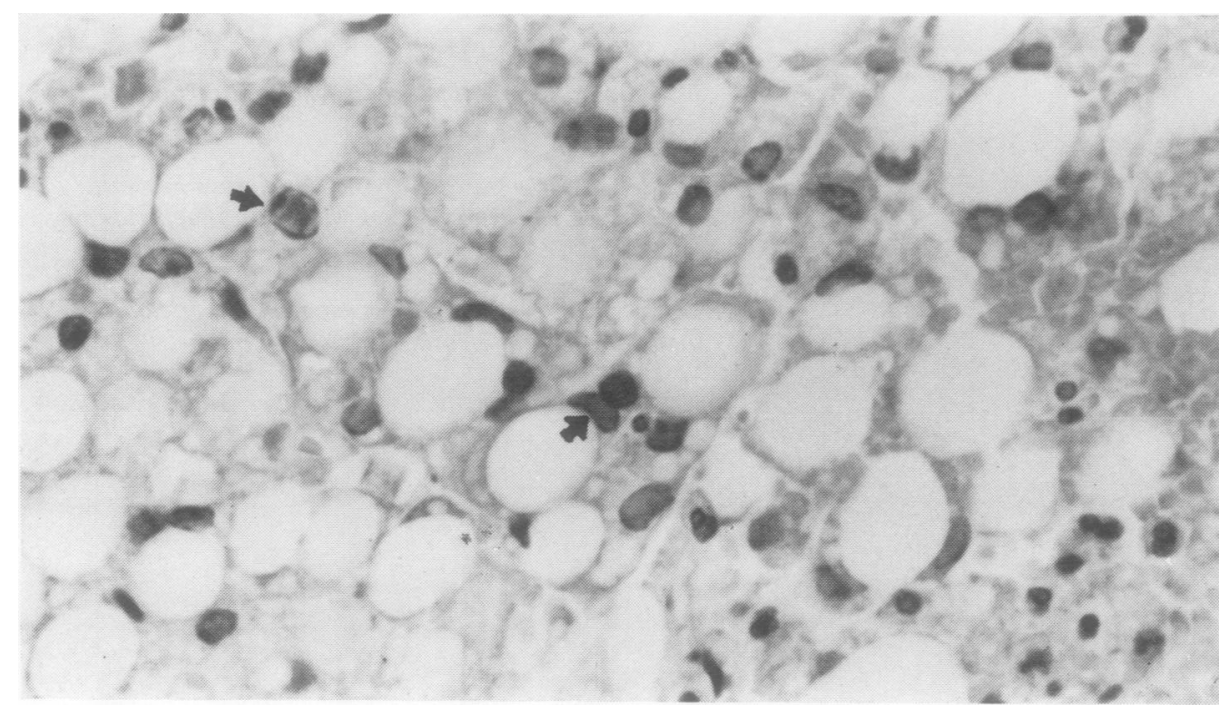

B Herpetic

inclusions

(arrowed) within the nuclei of liver cells at the periphery of the area of necrosis (haematoxylin and eosin.

$\times 480$ ). 
because of weight loss, diarrhoea, oedema, and ulceration of the mouth and nose. Examination showed a very ill, pale, malnourished child with purpura and hepatomegaly. The child was moribund and died on the day of admission. The morbid anatomical findings described in the necropsy report were, in retrospect, those of florid disseminated Herpesvirus hominis infection, which was the apparent cause of death. Review of the liver sections showed the characteristic herpetic lesions (Fig. 2). The aetiology of the striking morbid anatomical and histological findings was not appreciated at the time of necropsy.

\section{Case 3}

This 5-month-old Bantu male infant was admitted to hospital in coma with gastroenteritis. Two weeks after admission a right-sided pneumonia and empyema were diagnosed. The child died on the 27th day after admission. Necropsy showed septic cut-down wounds on the limbs and a right-sided lung abscess and empyema, which was considered to be the cause of death. The liver was fatty and many rounded yellow foci were noted on the subcapsular and cut surfaces. These areas of necrosis were regarded as non-specific. The present review of the histological sections of the liver showed that the focal necroses were herpetic in origin. Herpetic intranuclear inclusions were present, though sparse, and there was some histiocytic cellular reaction.

\section{Case 4}

A 12-month-old Bantu female presented with diarrhoea and pneumonia. After two weeks' treatment she was apyrexial with a normal chest radiograph. Ten days later her condition deteriorated and she died a few days after. Necropsy revealed bronchopneumoia, ulceration of the terminal ileum, and numerous tiny yellow foci scattered throughout the liver. These foci were originally interpreted as focal necroses due to septicaemia. Review of the histology showed herpetic inclusions in cells bordering the areas of necrosis (Fig. 3). In addition to the herpetic focal necroses, microscopy of the liver showed a few areas of congestion with masses of bacteria and inflammatory cells, probably the result of portal pyaemia.

\section{Case 5}

This 18-month-old Coloured male was admitted to hospital suffering from diarrhoea, vomiting, and conjunctivitis. A discharge from the left ear was also noted. Necropsy revealed ulceration of the tongue, pharynx, and oesophagus. Death resulted from pulmonary tuberculosis with cavitation and subacute miliary tuberculosis of the spleen was present.

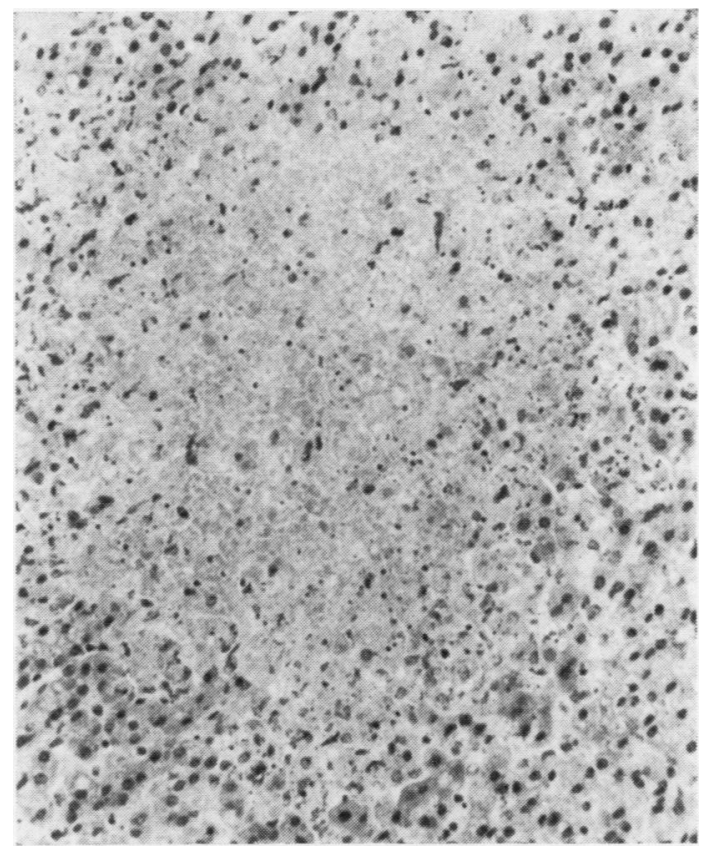

A Low-power view of an area of herpetic necrosis (haematoxylin and eosin, $\times 50$ ).

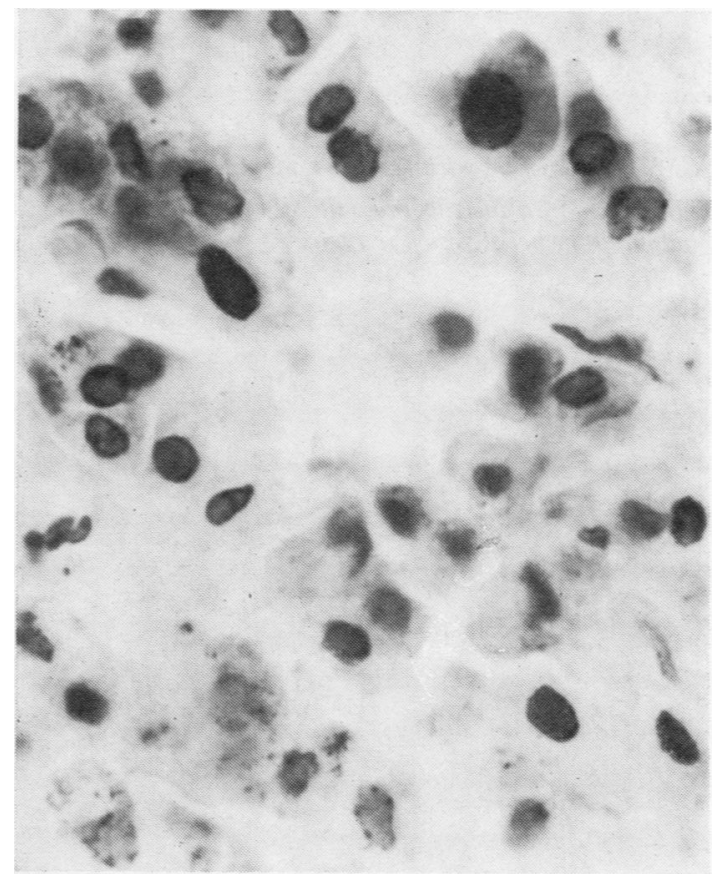

B Herpetic inclusion bodies in cells bordering the area of necrosis in the liver (haematoxylin and eosin, $\times 800$ ).

Fig. 3 Case 4: microscopy of the liver. 


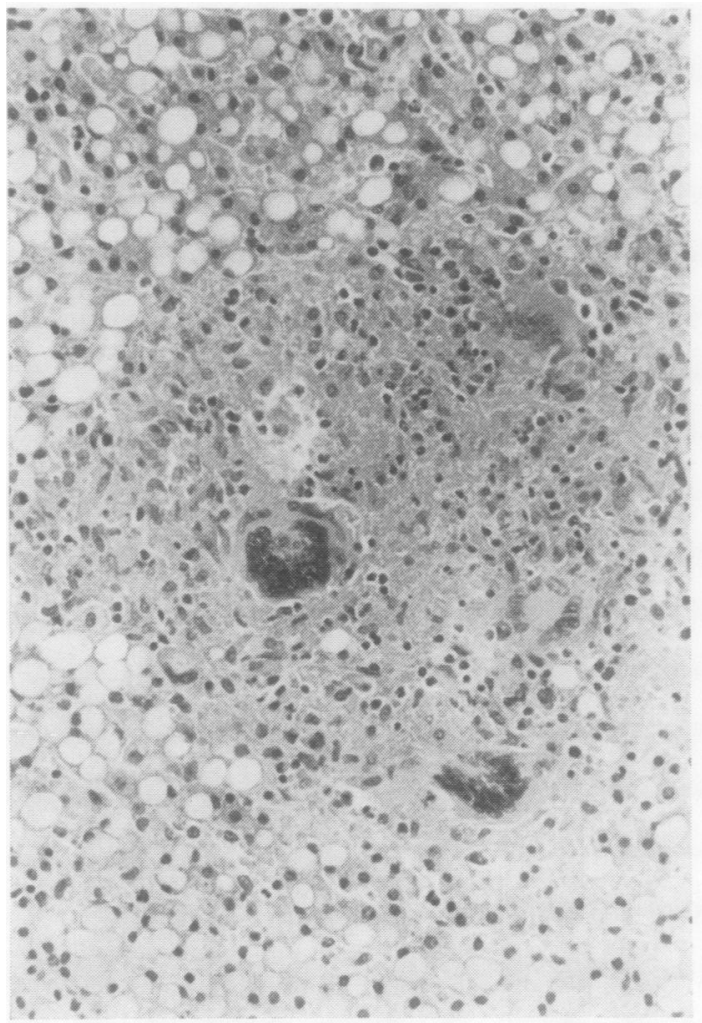

A Miliary tubercle with typical Langhans giant cells. The liver is fatty (haematoxylin and eosin, $\times 160$ ).

B In addition to the tubercles there were areas of herpetic necrosis. The herpetic lesion is surrounded by a zone of inflammatory cells, which is regarded as an indication of healing (haematoxylin and eosin, 30 ).

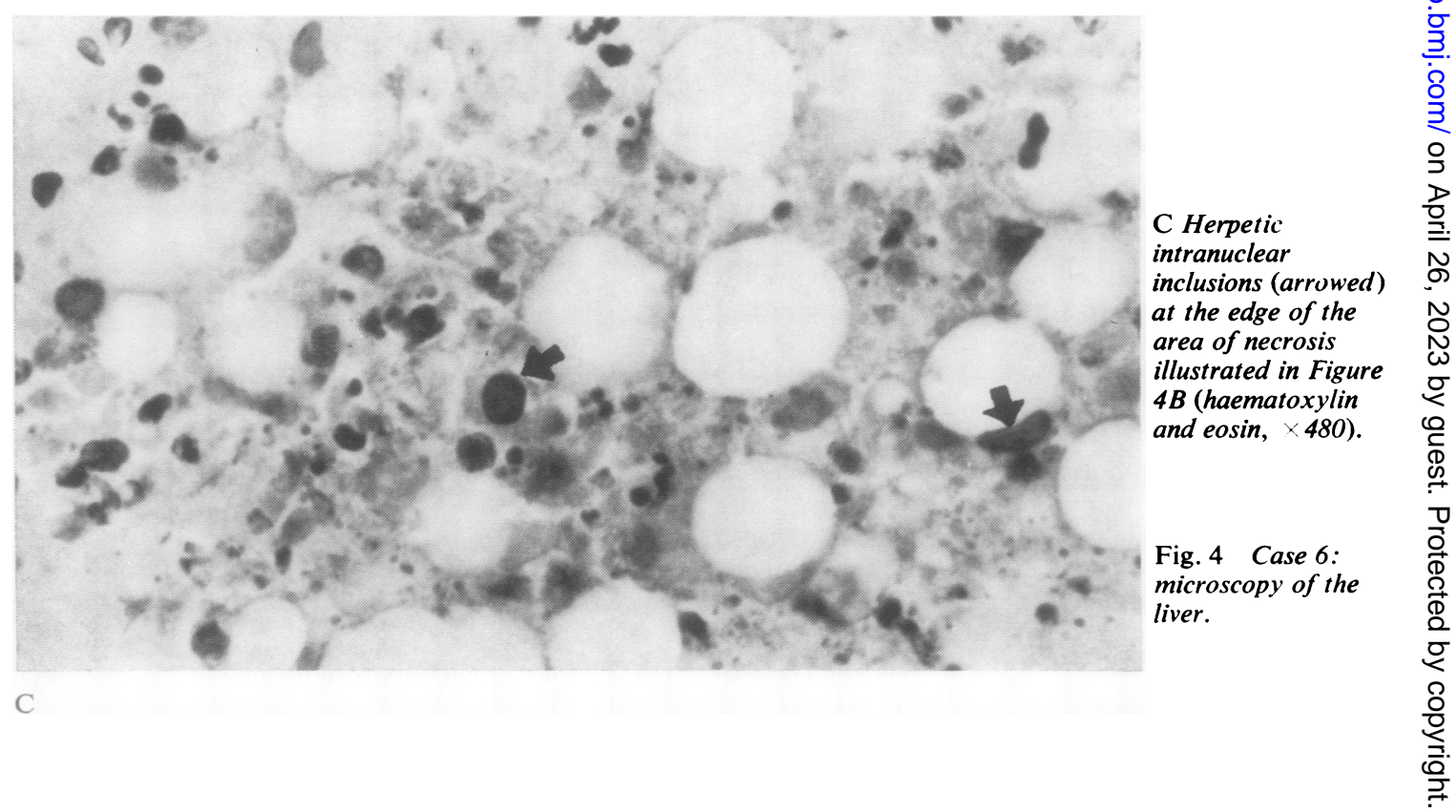


The necropsy report mentioned small, yellow-grey, rounded foci in the liver. Histologically these foci of necrosis were regarded as non-tuberculous but their herpetic nature was not recognized.

\section{Case 6}

A Coloured female aged 6 months developed stomatitis associated with pyrexia and died after a week in hospital. Necropsy showed emaciation, anaemia, stomatitis, pharyngitis, laryngitis, and oesophagitis. Death was due to a bilateral caseating tuberculous bronchopneumonia and miliary tubercles were present in liver and spleen. Microscopically, in addition to the miliary tubercles in the liver, there were sparse areas of focal necrosis which were not regarded as tuberculous. When the sections were reviewed, inclusions typical of a herpesvirus infection were seen in these areas of necrosis (Fig. 4).

\section{ELECTRON MICROSCOPY}

Herpesvirus particles were demonstrated in the liver lesions of all six cases by electron microscopy (Figs. 5 and 6). Similar particles were present in the livers of the mice infected with Herpesvirus hominis (Fig. 7). No viral particles were found in the livers of the five control necropsy cases, nor of the control uninfected mouse. Viral particles were demonstrated by electron microscopy with less difficulty in cases where the viral inclusions were prominent than in those where inclusions were scanty.

\section{IMMUNOFLUORESCENCE STUDIES}

Positive specific immunofluorescence was noted in areas of herpetic liver necrosis in the four mice inoculated with Herpesvirus hominis, but not in the liver of the control uninoculated mouse. However, specific immunofluorescence could not be demonstrated in the herpetic lesions of the livers of the six necropsy cases. The latter result was not unexpected since in our experience (unpublished observations) specific immunofluorescence of herpesvirus antigen in tissues is readily rendered undemonstrable if, as was the case, routine processing methods with prolonged fixation in $10 \%$ formol-saline are used; however if the fixation time in formol-saline is kept to the minimum required for adequate fixation,

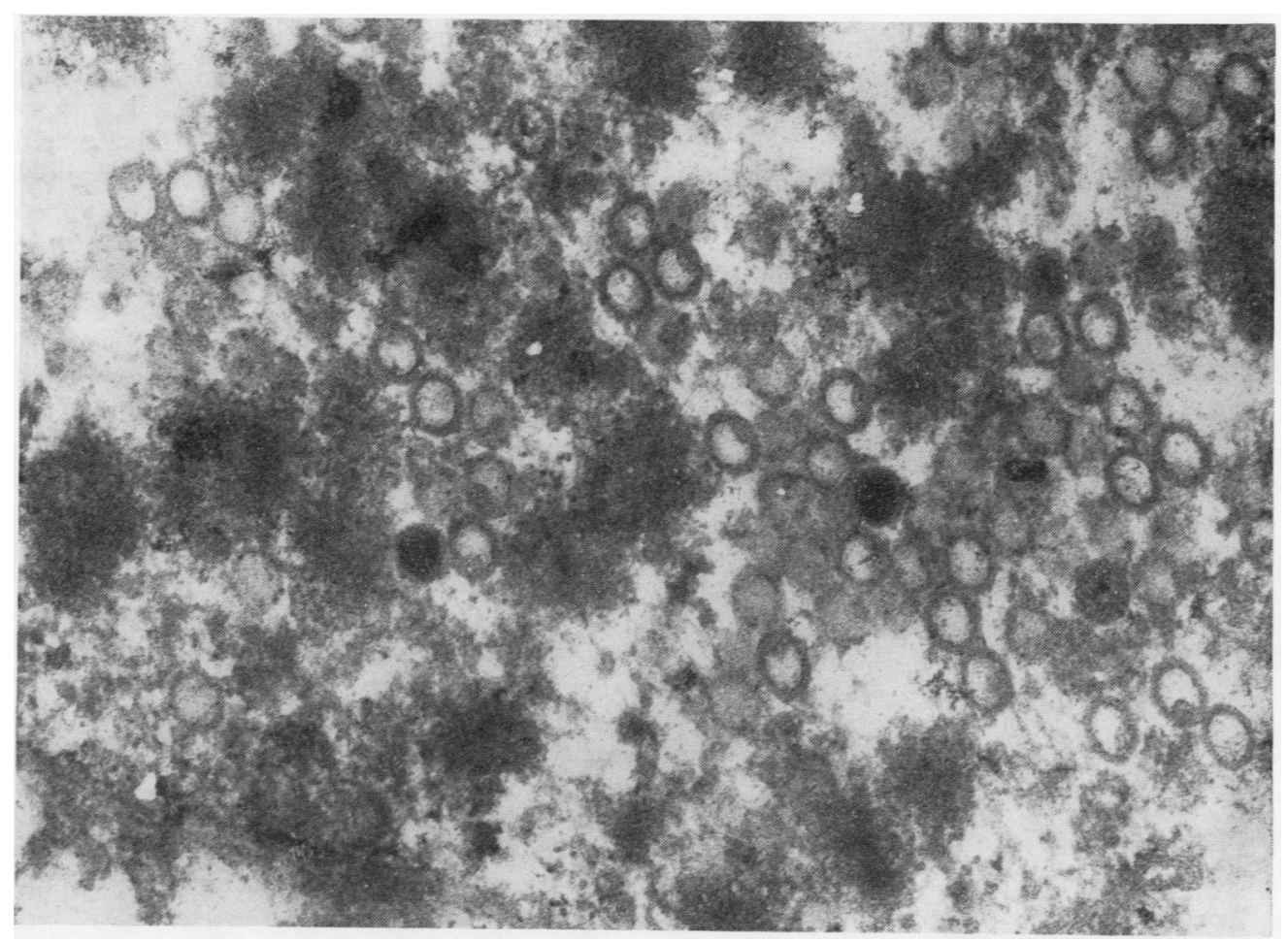

Fig. 5 Electron micrograph of an ultrathin section of liver from case 2. Naked herpesvirus capsids are present in the cell nucleus, $\times 60,000$. 

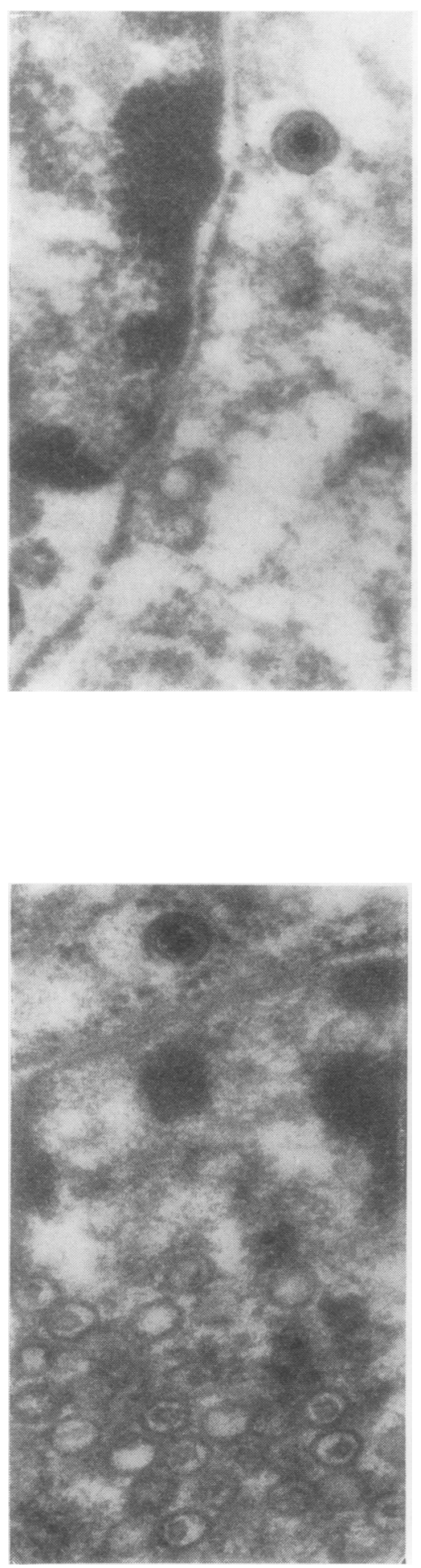

Fig. 6 Electron micrograph of an ultrathin section of liver from case 5. An enveloped herpesvirus particle is seen in the cytoplasm adjacent to the nuclear membrane, $\times 60,000$.

Fig. 7 Electron micrograph of an ultrathin section of the liver of an infected mouse. Naked herpesvirus capsids are present in the cell nucleus and an enveloped particle is in the cytoplasm adjacent to the nuclear membrane, $\times 60,000$. herpesvirus antigen may be demonstrated. Templeton (1970) achieved success in four of his six cases.

\section{Discussion}

Since the report by Hass (1935) many cases of visceral involvement in disseminated Herpesvirus hominis infection have been reported from various parts of the world and the subject is dealt with in textbooks (eg, Bedson, Downie, MacCallum, and Stuart-Harris, 1967).

This study has shown that classical florid cases of disseminated Herpesvirus hominis infection occurred both in the neonatal form and in association with malnutrition in older children in Cape Town before 1957 but that the diagnosis had been missed. The recognition of the disease in 1957 in Cape Town was therefore due to a new awareness of the disease and not to the emergence of a more virulent strain of herpesvirus. In establishing the diagnosis of disseminated Herpesvirus hominis infection, it was necessary to differentiate the disease from infection with other members of the herpesvirus group, namely cytomegalovirus and varicella virus. The histological distinction between lesions produced by cytomegalovirus and Herpesvirus hominis is not difficult. In the absence of virus investigations, disseminated Herpesvirus hominis and varicella virus infections can usually be differentiated with confidence by considering as a whole the epidemiological, clinical, morbid anatomical, and histological data. These aspects of Herpesvirus hominis infection have been considered elsewhere (Becker et al, 1968). The features of disseminated varicella have been described by a number of authors such as Johnson (1940); Cheatham, Weller, Dalan, and Dower(1956); Nicolaides (1957); Rotter and Collins (1961), and Triebwasser. Harris, Bryant, and Rhoades (1967). In particular, the absence of a skin rash in the patients in the present series is a strong argument against varicella. In addition, collateral epidemiological evidence of varicella would be expected, especially in those cases with a prolonged stay in hospital. Ideally confirmation of the aetiology can be obtained by specific immunofluorescence if the preparation and storage conditions of the tissues have been satisfactory. Electron microscopic examination of wax-embedded tissues is a feasible way of confirming the diagnosis of infection with a virus of the herpes group even if the tissues have been stored for long periods. In the present series the blocks had been prepared as long as 18 years previously.

Several features of these cases are worthy of comment. In cases 3,4 , and 5 the length of stay in hospital relative to the known incubation period of 
herpesvirus infection suggests that the infection was acquired in hospital at a time when the potential danger of cross-infection with herpesvirus was not appreciated. This view was supported by the fact that cases 3 and 4 were in the same ward at the same time, and were in fact consecutive necropsies performed on the same day. The neonate lived her entire life of 12 days in hospital and one may only speculate as to whether she acquired her herpetic infection from her mother or from some other source in the hospital. In the series reported by Templeton (1970), case 1 apparently contracted the herpesvirus infection while in hospital where he was for over three weeks. Of interest in cases 5 and 6 were the negative tuberculin tests in association with the miliary tuberculosis which suggests a state of anergy with diminished cellular resistance and presumably decreased resistance to the herpesvirus infection. Case 3 of Templeton's (1970) series was also associated with extensive tuberculosis. A good histiocytic cellular response in the liver lesions in case 6 and to a lesser extent in cases 3,4 , and 5 was a noteworthy feature. In these patients death was not directly attributable to the herpetic infection (Table I), and the herpetic lesion is seen at a later stage of its evolution than in cases 1 and 2 in which death occurred during the florid stage of the disease, and in which no cellular reaction was seen (Becker et al, 1968).

Following on the reports from Cape Town, similar cases of disseminated Herpesvirus hominis infection in older children in association with malnutrition or measles were reported from university centres in West Africa (Armengaud, Baylet, Camain, Quenum, Guerin, and Schluep, 1963) and East Africa (Templeton, 1970). These reports strengthen our belief that disseminated Herpesvirus hominis infection has 'always' occurred and is more common than published reports suggest.

We wish to thank Dr J. G. Burger, Superintendent, Groote Schuur Hospital, for permission to publish; Professor J. G. Thomson for access to necropsy material and helpful criticism; Professor A. Kipps for helpful criticism; Mrs P. McDowell and Miss K. Larsson for technical assistance.
References

Armengaud, M., Baylet, R. J., Camain, R., Quenum, C., Guerin, M., and Schluep, R. (1963). Note préliminaire à l'étude de la primo-infection herpétique de l'enfant africain (à propos de 244 observations). Bull. Soc. méd. Afr. noire Langue franç., 8, 358-375.

Becker, W. B. (1966). The epidemiology of herpesvirus infection in three racial communities in Cape Town. S. Afr. med. J., 40, 109-111.

Becker, W. B., Kipps, A., and McKenzie, D. (1968). Disseminated Herpes simplex virus infection: Its pathogenesis based on virological and pathological studies in 33 cases. Amer. J. Dis. Child., 115, 1-8.

Becker, W., Naude, Du T. W., Kipps, A., and McKenzie, D. (1963). Virus studies in disseminated Herpes simplex infections: association with malnutrition in children. S. Afr. med. J., 37, 74-76.

Bedson, S., Downie, A. W., MacCallum, F. O., and Stuart-Harris, C. H. (1967). Virus and Rickettsial Diseases of Man, 4th ed., p. 125 et seq. Arnold, London.

Cheatham, W. J.. Weller, T. H., Dalan, T. F., Jr., and Dower, J. C. (1956). Varicella: A report of two fatal cases with necropsy, virus isolation and serologic studies. Amer. J. Path., 32, 10151035.

Descarries, L. (1967). An improved method for preparing cultivated nervous tissue for electron microscopic study. J. de Microscopie, 6, 313-320.

Hass, G. M. (1935). Hepato-adrenal necrosis with intranuclear inclusion bodies. Amer. J. Path., 11, 127-142.

Johnson, H. N. (1940). Visceral lesions associated with varicella. Arch. Path., 30, 292-307.

McKenzie, D., (1961). Disseminated Herpes simplex infection. S. Afr. med. J., 35, 133-135.

McKenzie, D. Hansen, J. D. L., and Becker, W. (1959). Herpes simplex virus infection: Dissemination in Association with malnutrition. Arch. Dis. Childh., 34, 250-256.

Morecki, R., and Becker, N. H. (1968). Human herpesvirus infection -its fine structure identification in paraffin-embedded tissue. Arch. Path., 86, 292-296.

Nicolaides, N. J. (1957). Fatal systemic varicella: a report of three cases. Med. J. Aust., 2, 88-91.

Reynolds, E. S. (1963). The use of lead citrate at high pH as an electron-opaque stain in electron microscopy. J. Cell Blol., 17, 208-212.

Rotter, R., and Collins, J. D. (1961). Fatal disseminated varicella in adults: report of a case and a review of the literature. Wis. med. J., 60, 325-332.

Sainte-Marie, G. (1962). A paraffin embedding technique for studies employing immunofluorescence. J. Histochem. Cytochem., 10, 250-256.

Templeton, A. C. (1970). Generalised herpes simplex in malnourished children. J. clin. Path., 23, 24-30.

Triebwasser, J. H., Harris, R. E., Bryant, R. E., and Rhoades, E. R. (1967). Varicella pneumonia in adults. Report of seven cases and a review of literature. Medicine (Baltimore), 46, 409-423.

Zagury, D., Pappas, G. D., and Marcus, P. I. (1968). Preparation of cell monolayers for combined light and electron microscopy: staining in blocks. J. Microsc., 7, 287-292.

Zagury, D., Zeitoun, P., and Viette, M. (1966). Méthode d'étude de cultures de cellules par la Microscopie électronique: la Culture sur support d'épon. C.R. Acad. Sci. [D] (Paris), 262, 1458-1459. 